\title{
The Ascension
}

\section{Choreography of Ascent: Staging Images of Spirituality}

Father, send down a cloud for me!

I come to thee, my Father dear.

(Jesus, $11.175-6)^{\prime}$

In The Ascension, Jesus calls up to his heavenly father to request that a 'cloud' be sent down to accompany him on his journey from earth to heaven. The script clearly indicates a specific action taking place; first the cloud descends into the playing space, then somehow, Jesus and the cloud rise up and out of the view of the audience. This was the first special problem to be solved for this pageant. How were we to 'ascend' an actor mechanically on a small wagon space in a convincing and meaningful manner? Such a stage direction would be easily managed in our modern theatres, and could be magnified with all the special effects possible through complex technology. For medieval audiences at York the very special effect of this pageant presumably was no less exciting - even without our technical bravado. On a pageant wagon pulled through the streets of York in full view of all folk who wished to vicariously participate, the Ascension of the Lord, one of the key events of Christian history, was brought to life. This event may have been staged simply by the use of winch and pulley, but it was spectacular in that it represented to medieval believers the very possibility of their own union with God through Christ.

As a director I chose to explore the theological significance of this pageant as understood by medieval audiences. My interest was in portraying a representation of medieval spirituality connected to the notion of the Ascension. Two issues drew me to this approach. Most notably, the text of the Ascension is unique in the York Cycle because of its long monologue for Jesus. This monologue presented the second problem for the staging of our pageant - the challenge of holding the audience's interest and the tension of the drama throughout this preaching of a long theologically complex sermon. As a further complication for contemporary dramatization, the text presents concepts and a focus on the Ascension no longer emphasized and recognized by the general 
population today. Thus the Ascension is not an episode modern audiences can identify with as readily as they are able to with other biblical stories like the Nativity, Crucifixion, or Resurrection. Therefore, to visualize the fifteenthcentury religiosity of this pageant, I sought to bring the theology underlying the text into focus through a series of staged images. A thoughtful rendering of the performance in medieval terms would depend upon an exegesis of the many levels of the drama including the scriptural foundation, traditional theology, and medieval spirituality. Out of this 'performance theory' grew a style for delivery of spoken text, symbolic movement and gesture, central iconographic images and secondary iconographic images. This approach eliminated the need to focus too exclusively on arguments attempting to determine probable medieval acting style or medieval production design as an external exercise and hopefully lead away from a superficial performance of modern actors 'acting' medieval. Instead staging and acting were morivated directly out of that period's sacred images and writings, which, through internalization, expressed the basic concepts of the pageant with a sense of immediacy. Especially for this pageant it was essential that the actors understood the intellectual mind-set inherent in the text if they were to communicate the message effectively to the modern audience. Toward this end, my production design began with an analysis of Ascension theology in comparison with that expressed in the text by the dramatist at York.

The climactic moment of the Ascension drama, as Jesus is hoisted up above the heads of the earthbound crowd below, presents one theological climax in the story of the fall and redemption of humankind which comprises the subject matter of the York Cycle. Of all the pageants in the York Cycle, it is in The Ascension that Jesus is given his longest speech. It is meaningful that at this event alone the dramatist has chosen to give Jesus his major dramatic monologue. The speech comprises half of the pageant, taking 147 lines, in which Jesus is made to teach and review the complete spiritual message of redemption. Another unique feature of this dramatization is that there is no exchange of true dialogue between Jesus and the other characters at the Ascension, in contrast with other pageants where Jesus does engage in dialogue. This fact points to a clear intent on the part of the dramatist to construct the Ascension event as a didactic moment where the audience is meant to be drawn into identification with the action as a learning/meditative event. The audience becomes like the apostles, called to witness the final moments of Jesus' physical time on the earth and privileged to hear his final teaching. The symbolic lifting up of their own souls with Jesus is the participatory effect at the climax of the Ascent. 
Through the dramatization of Scripture in this pageant of the York Cycle, the staging of The Ascension underlines its theological significance and provides a visible representation of a spiritual reality. Several key concepts are presented through the text. Foremost among these is that Jesus emphasizes to the apostles his future role as their intercession in heaven. This is clearly seen in these lines in which Jesus directly addresses God the Father in heaven on behalf of the disciples:

Therefore Father, bless these men in faith and trust,

so that they may be one as we are in heaven.

York's Jesus has also asked the Father for reconciliation saying:

Part them not from our company, since thine are mine and mine are thine.

Since they are ours, if they need aught,

Do help them if it be your will.

Doctrine of the Ascension includes the notion that Christ's humanity was taken into Heaven. The early image of Christ as 'first fruits' is found in 1 Corinthians 15:20-3, and was presented by Crystostom who wrote, Jesus 'ascended up to heaven, and taking up the flesh from us took possession of his Father's throne, in order that he might work reconciliation for his servants.... He makes available to us a feast in honour of victory over the devil...'2 This meaning of the Ascension was later explicated by the Dominican philosopher and theologian, St Thomas Aquinas in the thirteenth century. Commenting on the Ascension in his Summa Theologiae Aquinas wrote, "by his Ascension, he prepared a way for us to heaven. The presence of his human nature in heaven is itself an intercession for us... enthroned in heaven as God and Lord, Christ from above showers upon men his divine gifts'.

In the scene before he rises, Jesus tells the apostles gathered there of the critical importance of this event and the importance of the Ascension to their lives:

I must go hence: needful is this.

You shall not know, unless I mount,

The comforter of comfortless.

And if I wend you shall find how

I'll send him down, of my goodness.

$(11.167-71)$

As Jesus explains, he cannot remain on earth with the apostles, he must take his place at the right hand of the Father. This concept was clear to the believing 
community through the Creed which included the confirmation that Jesus 'ascended into Heaven and sitteth at the right hand of the Father'. From this exaltation Jesus provides intercession for all believers (Romans 8:34) and he sends the Holy Spirit - 'the comforter of comfortless' - out into the world to continue to work for the word of God through the apostles. The gift of the Holy Spirit comes to the apostles at Pentecost and strengthens them to carry out the commission Jesus has given them - to be his witnesses in the world. The text of the York Ascension illustrates this call to the disciples (and to the audience) as it follows the story of Acts 1:1-9 which describes the church's mission and predicts the coming of the Holy Spirit.

A background in this theology of the text informed the direction I took in developing the production design. I turned next to finding images reflective of these concepts. The central images would of course portray the climactic moment of the Ascent as described in scripture. In chapter one of Acts, where the Ascension of Jesus is most fully described, the reaction of the apostles to the event is narrated by two angels who have unexpectedly arrived on the scene. They said, 'Men of Galilee, why do you stand looking up toward heaven?' (Acts 1:10-11) Ascension iconography emerged during early Christianity portraying this dramatic moment. The Rabbula Gospel, dated 586, portrays the basic elements of the narrative in its Ascension illustration. Christ is in full view surrounded by the mandorla as the focus at the centre of the illustration. Angels appear to hold the sides of the mandorla and accompany or assist the process of ascending. This is an imagined view, as if the artist or observer were in the sky moving up with Jesus. On the ground below, the apostles stand with their heads turned upward, some gesturing or pointing skyward. Meanwhile, two angels - the 'men in white' described in Acts - appear to be explaining events to the apostles. Standing between the two groups of the apostles, the Blessed Virgin Mary stands as a central focus of the composition.

Mary's inclusion at the Ascension is not scriptural; she is not mentioned at the event as described in Luke-Acts, or Mark. This early image presents, however, symbolic attributes of Mary which are also evident in her portrayal in the York Ascension. The figure of Mary plays a central role in Ascension iconography where her presence gives representation to the theological aspects of Christ's body and soul joining with the Father in heaven. Mary signifies the humanity of Christ, taken through her, in assurance that human nature truly was elevated to join the sphere of the divine as part of the redemptive process included with the Passion and Resurrection. As Mother of Christ, Mary also becomes The Mother of the Church representing on earth what Christ has established. Mary is a figure of strength in this text. When the apostles appear 
confused it is she who provides answers and reassurance, as seen in her answer to Peter:

Some things he said would come; they came,

Some yet will come; but each thing you did hear,

whether it be come or nay,

We ought believe together here.

The drama of the York Ascension enacts Mary's symbolic attributes where, through dialogue both didactic and devotional in intent, opportunity for affective piety is provided for the audience as a result of their identification with Mary.

A distinctive new Ascension iconography developed in eleventh-century England. This depiction did not show a full portrait of Christ in the sky, but instead showed only the bottom of the robe and the feet of Jesus as if this last glimpse of Jesus at the very moment he disappeared into the clouds were imagined from the vantage point of the apostles gazing upward. This image, called the Disappearing Christ by Meyer Shapiro, became the standard English iconography of the Ascension. ${ }^{4}$ In York this image is found in early-sixteenthcentury glass at York Minster and in fourteenth-century glass at All Saints, Pavement. ${ }^{5}$ The image of the Disappearing Christ that played to my dramatic imagination was found in the Ascension illustration from the Bolton Hours (c 1420). ${ }^{6}$ This drawing is crude and cartoon-like; there is little differentiation or individuality in the figures gathered at the bottom of the frame. They are divided into two groups that 'split centre' in stage terms, half face left and half face right. The downstage figures gesture upwards with their hands raised, palms opened. John is presumably the figure left of centre while Mary on the right of centre is distinguished by the decoration on her robe. At the top of the frame, the feet of Jesus hang in midair and meanwhile his body has disappeared into a three-tiered row of undulating curtains. My first reaction to this illustration was from a theatre perspective; to my mind, it looks like a staged blocking. The curtains are reminiscent of those used to mask the top of a stage. The characters are blocked into a space that appears to be structurally limited. While Mary and John form a central focus, the other apostles are stacked up in a very tight frame. Compared with other Ascension illustrations, this is an image that would fit if it were transferred to a pageant wagon - played in the end-on perspective! The spatial orientation of this illustration seems to mimic the spatial dimensions of the wagon and therefore the image could believably be brought to life like a 'living book' in a wagon production. Because of the restriction in size of the 
wagon, the image in performance would necessarily be expressive of the spatial qualities of the original illustration. Therefore this became the primary image of my production design and dictated the style for the reconstruction. Once this image was established as a type of tableau vivant for the Ascent moment the directing task was to develop, by working through the text, a meaningful blocking that would lead up to that image. In the same manner, it was necessary to work toward a natural progression out of the image after the Ascent was completed. To develop the blocking surrounding the Disappearing Christ. I drew inspiration again from visual arts, establishing a series of secondary images that expressed particular spiritual or theological ideas in the text. These were carefully composed to suggest illustrations even though they were not held static for long periods but were moved through freely with the intent of didactically highlighting the spoken words. The actors were guided through these movements in a choreographic method, directed from movement analysis and working toward a flow from image to image. Thus, the piece was composed for performance on two levels. On the first level the text expressively and rhetorically spoken was considered and on the second level movement sequences were developed which could communicate to the observer the feeling of the text in action without the dialogue. In other words, I attempted to choreograph the blocking so that even for viewers who might not hear the text, the visual sequences would indicate something of the meaning of the drama.

Two examples of staged scenes will suffice here as examples of the method described above. Jesus explains the necessity of his crucifixion to 'buy' mankind from the 'fraud' of Satan, using the image of the tree as the instrument of original sin and thus the appropriate instrument of Christ's redemptive suffering. Jesus announced to the audience:

In a tree through guile man was betrayed; and therefore man, to mend that miss bought mankind on a tree in trade.

At this point in the pageant, Jesus was speaking from the wagon while the apostles and Mary remained on the ground at the audience level. I directed the blocking at this moment to suggest the exalted status of Jesus (thus visually elevated) while the apostles remained earthbound because they were being taught but did not yet understand. At the beginning of this dramatic beat, then, Mary's exalted status as Mother of God and her role as the instrument of the Incarnation was signified by her movement away from the apostles and up onto the wagon as Jesus actively gestured for her to join him. At the phrase 'tree in 
trade', Jesus extended his arms to visualize the Cross while Mary turned to a posture of grief imitated from visual representations of the Crucifixion. The effect was to compose an illustration of the Crucifixion. As the text spoke then to the Crucifixion, the performance illuminated the Cross. In this way we sought to communicate an interplay between the theology, the text, art, and performance.

As the pageant concluded Mary's role as intercessor to her Son was again emphasized while adulation of her by the apostles was made evident. Mary promised the apostles just rewards as she told them:

My brothers dear, I trust it well

My son shall reward all your travail.

The image I chose to stage here, the Virgin of Mercy, illustrated her function as intercessor suggested by the text and further suggested the medieval ideal of Mary as the protector of all segments of society. The iconography I used was taken from the Bedford Hours. ${ }^{7}$ This image shows Mary, crowned as Queen of Heaven, holding the infant Jesus. Her cape is opened to reveal beneath it various groups of the faithful, including a king and queen and religious leaders kneeling to her in supplication. As this image was translated into dramatic action, Mary walked to the front edge of the wagon while the apostles (except Peter) and the audience were gathered below her. She extended her cape in imitation of the iconography and held that position for a beat to recreate that image of the faithful encompassed by her protective aura. She was then respectfully and chivalrously escorted down the steps of the wagon by the apostle John into whose care Jesus had entrusted her. ${ }^{8}$ Mary remained at the centre of the final image of the pageant. This illustrated her importance in medieval piety and was reminiscent of her central role as Mother of the Church seen in traditional Ascension iconography.

When the time arrived to bring our staging to Toronto for the performance, it was gratifying to see these images and our blocking adapt so well to the space of the pageant wagon. Our company experienced only one major technical difficulty which we discovered at the last minute. When Jesus called up, 'Father send down a cloud', the cloud (which was attached to a swing for Jesus to sit upon to be ascended) would nor descend from the top of the second level. There was no time to solve the problem from a technical standpoint. We were left to find an inspired solution within the theological framework that had shaped our reconstruction. Luckily, such inspiration came immediately. Our cast was blessed with a commandingly tall Jesus. What would Jesus do? I directed him to proceed with all majesty and authority to reach up into our heavens and pull the 
cloud down. After all, this action by Jesus would be appropriate and spiritually motivated, as Jacobus de Voragine reported in the thirteenth century:

He ascended powerfully, because he did so by his own power....admittedly he ascended in a globe of cloud, but he did not do this because he needed the help of a cloud, but to show that every creature was ready to serve its creator. ${ }^{9}$

Our Jesus pulled his own cloud from heaven to show his power. In performance, this was a solution that worked. Our audiences found the humour in Jesus taking command over the obvious frailty of our very human plans. I would like to think that laughter from the audience at that juxtaposition of the imaginatively divine and realistically human let us know that the audience had indeed been with us through our long and theologically complex speech.

Interacting with the design of conscious image-making as a method of performance was the opportunity for audience interaction. The entrance of Jesus was one such instance which provided a dramatic opportunity to include the audience in the play both spatially and interactively. As the pageant opened, we kept Jesus out of sight while the focus was established on the wagon and the dialogue between Mary and the apostles. Suddenly Jesus made his entrance from behind the crowd causing a moment of surprise as his voice and presence commanded the attention of all. This blocking suggested the miraculous and unexpected sense of the appearances of Jesus. Setting Christ in the midst of the people with the blood of his wounds glistening in his hands and feet drew them into the immediacy of the action and later helped us to convey the implication of the audience in the crucifixion as intended by the text with these lines spoken by Jesus:

And me, your son, whom you did send

to die for man to ease his plight

Mankind was yours, and you their friend

And they looked after me, alright

I died for man his miss to mend,

was done to death by means of spite.

At each station this proved to be a dynamic moment. The audience reaction was laughter as the guilt the text implied was immediately understood. God's friendship was returned by hate and sin by man.

Another such opportunity presented by the text for audience involvement and implication came with the appearance of the two 'men in white' - which 
in our case were cast as two female angels. These angels brought to the apostles and the audience apocalyptic messages of the Second Coming and foreshadowed with certain trepidation the Last Judgement. The first angel appeared and played this speech amidst the audience:

Come down again, just so, shall he with bleeding wounds in feet and hands Those who lived well, full glad will be Those who lived ill in dread shall stand.

The direction for this angel was to pick out one guilty-looking soul from the audience and pronounce damnation on him as one who 'lived ill'. A perfect contrast was provided at the second station where three beautiful young children with eager angelic faces had sat themselves in front of our wagon absorbed in the play. These innocents became part of the play as an example of those who 'lived well' as the angel gestured to them. Our audience, a group of strangers who were mostly anonymous to each other, found the message of doom amusing. One cannot help but ponder on how seriously the medieval audience would have reacted to such strong admonitions from the angel and whether the actor then would have singled out a guilty neighbour to warn of judgement.

As for our pageant reconstruction as a whole, it was not important for our modern audience to consciously recognize the iconography we were imitating. But it was critical that they be drawn into the story by that imagery. Nor were we in any way attempting to produce a realistic reconstruction of how the Tailors and their acting company might have staged the Ascension. Rather, our goal was to present a thoughtful and engaging portrayal of The Ascension pageant while suggesting what it might have meant spiritually to its contemporary medieval audience. Whether we succeeded in that goal, only God - and the critics - know.

Notes

1 All lines quoted from the York Ascension pageant are taken from the unpublished modernization by Chester Scoville and Kimberley Yates.

2 Chrysostom in Patrologia Graeca, as cited by Peter Toon, The Ascension of Our Lord (New York, 1984), 130.

3 Thomas Aquinas, Summa Theologiae, C. Thomas Moore (ed), 3a.53-9, Blackfriars edition (New York, 1976), vol 55, 97. 
4 Meyer Schapiro, Late Antique, Early Christian and Medieval Art (New York, 1980). For further discussion see also, Robert Deshman, 'Another Look at the Disappearing Christ: Corporeal and Spiritual Vision in Early Medieval Images', The Art Bulletin 79 (1997), 518-46.

5 Clifford Davidson, From Creation to Doom (New York, 1984), 160.

6 Davidson, From Creation to Doom, plate 15.

7 Janet Backhouse, The Bedford Hours (London, 1990), plate 31.

8 Mary's costume was modeled after the Bedford illustrations; blue linen lined with white (representing the ermine) and edged with a thin gold line bordered by gold dots. Inspiration for the apostles' costumes came also from this source.

9 Jacobus de Voragine, The Golden Legend, translated by William Granger Ryan (Princeton, 1993), 292. 